\author{
Mirjana Matea KovaČ*, Damir Horga* ${ }^{*}$ \\ *University of Split, Faculty of Electrical Engineering, \\ Mechanical Engineering and Naval Architecture \\ ** University of Zagreb, Faculty of Philosophy
}

\title{
Ponavljanja kao oblik govorne disfluentnosti
}

Ključne riječi: disfluentnosti, ponavljanja, samonadgledavanje, samoispravljanja

\section{Uvod}

Mehanizmi govorne proizvodnje su hijerarhijski organizirani procesi u kojima informacija prolazi transformaciju s jedne razine na drugu, pri tome mijenjajući adekvatne kodove i oblike materijala, karakteristične za određenu razinu (Horga 2008). Proizvodnja govora uključuje četiri osnovna procesa: a) konceptualizaciju, odnosno planiranje sadržaja izričaja; b) formulaciju, koja uključuje gramatičko, leksičko i fonološko kodiranje poruke; c) artikulaciju, koja predstavlja proizvodnju riječi; te d) samonadgledavanje ili monitoring, koji podrazumijeva provjeravanje točnosti ili prikladnosti proizvedenog izričaja. Dok planiranje poruke u proizvodnji materinskog jezika $(J 1)^{1}$ zahti-

1 Jezik koji se prvi usvaja je J1, dok je drugi jezik koji se usvaja ili uči J2. Mildner (2003) upotrebljava izraz usvajanje za prvi jezik, koji se odvija na neformalan način, dok se drugi jezik podučava formalnim metodama učenja. Prvi se jezik pohranjuje u nedeklarativnom, a drugi u deklarativnom pamćenju. Dva jezika koriste i različita područja mozga, prvi je jezik predstavljen u bazalnim ganglijama i nekim kortikalnim područjima velikog mozga, dok je drugi jezik rasprešenije predstavljen u moždanoj kori (Erdeljac 2009). U radu će se koristiti izrazi J1 i J2. 
jeva pažnju, oblikovanje i artikulacija izričaja su automatizirani procesi, koji mogu raditi paralelno bez svjesnog napora govornika. Međutim, unatoč automatiziranoj prirodi materinskog jezika, govornici ne proizvode savršen govor, već na različite načine oklijevaju, zastajkuju i ponavljaju dijelove izričaja ili griješe (Horga 2008). Disfluentnosti su dominantne u spontanoj ljudskoj komunikaciji, a javljaju se kao popratna pojava govornog planiranja i pokušaja da se uskladi govorni izraz s ostalim kognitivnim procesima. "Disfluencies are phenomena that interrupt the flow of speech and do not add propositional content to an utterance“" (Fox Tree 1995: 709). Tu su uključene stanke, prekidi unutar fraze ili riječi, ponavljanja, ponovna započinjanja prekinutih izričaja, produžavanje vokala te zvučne stanke (engl. filled pauses), kao što su $u h$ i um. Poteškoće se mogu pojaviti na bilo kojoj razini procesa proizvodnje govora, odnosno za vrijeme planiranja poruke, leksičkog prizivanja i artikulacije govornog plana. Postoji stajalište da je kognitivni napor uzrok disfluentnostima, a potvrđen je u istraživanjima u kojima se disfluentnosti pojavljuju ispred dužih izričaja (Shriberg 1994) ili ako je tema nepoznata (Bortfeld i sur. 2001). Govorna proizvodnja je vremenski kontinuiran proces u kojem govornik raspoređuje svoje vrijeme koje ima na raspolaganju na periode planiranja informacije, jezičnu i artikulacijsku strukturu poruke te trenutke realizacije planiranog. U ovom složenom procesu neke komponente u mehanizmu govorne proizvodnje mogu zakazati i tako nastaju pogreške koje predstavljaju semantičku buku koju je proizveo sam govornik (Horga 2008). Jaeger (2005) promatra govornu proizvodnju kao sustav koji razlikuje dvije temeljne razine. Prva razina uključuje znanje o svijetu koje je pohranjeno u dugoročnoj memoriji na temelju koje će govornik organizirati informacijsko/sadržajnu/ konceptualnu komponentu govora. Tu se nalazi i znanje o jeziku i mehanizmi govora, koji govorniku omogućuju informaciju pretvoriti u lingvistički oblik, to jest govor. Druga razina procesiranja uključuje mehanizme pomoću kojih govornik priziva, izabire i aktivira komponente iz dugoročne memorije i ugrađuje ih u trenutni izričaj stvarajući govorne oblike. Neidealno funkcioniranje se može pojaviti na obje razine zbog nesavršenih programa govorne proizvodnje ili zato što realizacija programa u nekim trenucima može zakazati. To mogu biti različiti oblici disfluentnosti ili zastoja, koji uključuju prekide i ponavljanja izričaja koji su korektno izvedeni, te otvorene (čujne) pogreške koje se ispravljaju ili ne ispravljaju (Horga 2008). 
Nakatani i Hirschberg (1994) navode da 10\% izričaja u J1 uključuje neku vrstu ispravka, a Fox Tree (1995) ističe da govornici proizvode oko 6 disfluentnosti na 100 riječi. Nooteboom (1980) zaključuje da 50\% pogrešaka u J1 ostaje neispravljeno. Razlog neotkrivanja pogreške može biti što mehanizam nije otkrio pogrešku ili je govor dovoljno redundantan, tako da sugovornik može pravilno interpretirati poruku u nesavršenom obliku bez ispravka.

Dell (1986) smatra da pogrešna aktivacija određenih čvorova uzrokuje pojavu govornih pogrešaka. Realizacija određene jedinice ovisi o stupnju njene aktivacije, ali i o aktivaciji drugih jedinica koje predstavljaju asocijativno organiziranu mrežu čvorova. Jedinica koja je u postupku realizacije u određenom trenutku mora biti deaktivirana kako bi ispraznila mjesto i ustupila ga drugoj jedinici. Ponavljanja su oblici govorne disfluentnosti koja nastaju zbog problema u planiranju ili kao rezultat produžene aktivacije nekog elementa i nedovoljne aktivacije sljedećeg koji bi ga trebao zamijeniti (Horga 2008). Pojedini autori ponavljanja klasificiraju kao prikrivena ispravljanja zbog nepostojanja površinske pogreške i pretpostavke da se pogreške ispravljaju prije artikulacije (Levelt 1989, Postma i Kolk 1992). Ponavljanja, kao i poštapalice, mogu biti i u funkciji „kupovanja vremena”, odnosno u službi rješavanja problema u planiranju izričaja, te na taj način omogućavaju govorniku ostati u komunikaciji i onemogućuju sugovornika da preotme riječ (Rieger 2000). Fox Tree (1995) je proučavajući ponavljanja i pogrešna započinjanja izričaja (engl.false starts) kao oblike govorne disfluentnosti zaključila da se narušena sintaksa u slučaju pogrešnih započinjanja izričaja može negativno odraziti na proces razumijevanja poruke i rezultirati povećanim kognitivnim naporom prilikom procesiranja nove poruke. S druge strane, kod ponavljanja nema promjene u obavijesnom sadržaju, te se ne mijenja prvobitna sintaksa ili semantika, nego se samo ponavljaju govorni odsječci koji ne rezultiraju problemima $u$ procesiranju.

U idućem poglavlju su iznesene psiholingvističke teorije monitoringa koje pokušavaju objasniti kako govornik nadgleda vlastiti govor, odnosno kako sustav otkriva pogrešan ili neprikladan izlazni podatak. Iako disfluentnosti poput ponavljanja, poštapalica ili produžavanja vokala ne ukazuju na pogrešku u pravom smislu, njihovo prisustvo ipak može upućivati na samoispravljanja koja nisu direktno manifestirana na površini (Levelt 1989). Ponavljanja prvenstveno kraćih govornih odsječaka se mogu objasniti Dellovom (1986) teorijom širenja aktivacije ili sposobnošću artikulatora da samo- 
stalno započne izričaj (engl. restart). U trećem poglavlju naglašen je cilj rada i metodološki postupci, a u četvrtom su izneseni dobiveni rezultati uz odgovarajuću raspravu.

\section{Fenomen ponavljanja i teorije monitoringa}

Postojeće teorije monitoringa razlikuju tri ključna termina: monitor, filter i editor. Berg (1986: 134) definira monitore kao „mentalne oči” koje prate tijek planiranja i procesiranja poruke. Činjenica da monitor može samo ,promatrati“ što se događa, implicira pretpostavku da monitor nema mogućnost uplitanja u procese. Suprotno monitorima, filteri imaju sposobnost "vetoing the material prepared for articulation" (Berg 1986: 134). Editori nadopunjuju filtere "by replacing a vetoed item by a more acceptable or appropriate one" (Berg 1986: 134). Osnovni teoretski pristupi monitoringu uključuju teorije editora (engl. editor theories), teorije monitoringa šireće aktivacije (engl. spreading activation theory of monitoring) i teorije perceptualne petlje (engl. perceptual loop theory), pri čemu se posebna pažnja obraća na objašnjavanje fenomena samoispravljanja govornih pogrešaka.

Editorske ili uređivačke teorije monitoringa pretpostavljaju postojanje uređivača koji je zadužen primijetiti i zamijeniti neispravni izlazni podatak procesa govorne proizvodnje. Jedna je mogućnost da uređivač ima svoj vlastiti sustav pravila koji provjerava ispravnost izlaznog podatka. Baars, Motley i MacKay (1975) te Motley, Camden i Baars (1982) su razvili model u kojem predartikulacijski uređivač provjerava izričaj neposredno prije artikulacije koristeći kriterije leksičkih zakonitosti, sintaktičke i semantičke prikladnosti, situacijski kontekst, te društvenu prikladnost. Međutim, kada bi ovaj mehanizam radio savršeno, on ne bi dopuštao pojavljivanje pogrešaka, što u stvarnosti nije slučaj. Autori navode moguće razloge neispravljanja: sustav pravila koji koristi ovaj mehanizam je degenerativan (Garnsey i Dell 1984) ili se pravila u određenom trenutku mijenjaju (Motley, Camden i Baars 1982). U drugom slučaju će primjena određenog pravila ovisiti, između ostaloga, o kontekstu i dostupnoj pažnji. Garnsey i Dell (1984) tvrde da se postojanje predartikulacijskog uređivača, koji sprječava pojavu pogrešnog i neprikladnog izlaznog podatka, može potvrditi u istraživanjima eksperimentalno uvjetovanih pogrešaka, takozvanim fenomenom ,na vrhu jezika“ (engl. tip of the tongue) (Baars, Motley i MacKay 1975, te Motley, Camden i Baars 1982). 
Nedostatak ovog modela je u tome što uređivač može provjeriti isključivo završni proizvod procesa i nije u mogućnosti otkriti pogrešku na posrednim razinama. Nadalje, znanje koje je potrebno kako bi se donijela odluka o prikladnosti predartikulacijskog izlaznog podatka mora biti reduplicirano, što je krajnje neekonomično (Berg 1986, Levelt 1989).

Kako bi se eliminirali neki problemi koje teorija predartikulacijskog uređivanja ne uspijeva objasniti, nekolicina istraživača (Nooteboom 1980, Norman 1981, Postma i Kolk 1992) pretpostavila je postojanje specijaliziranog monitora na svakoj razini sustava procesiranja, koji nadgledava ispravnost izlaznog podatka na zadanoj razini. Ova inačica uređivačke teorije naziva se produkcijska teorija monitoringa (engl. production theory of monitoring), zato što monitor ima pristup različitim fazama proizvodnje. Međutim, i u ovom slučaju bi monitor trebao sadržavati isto ili približno isto znanje kao i procesna komponenta. Kada bi monitor zadržavao proces proizvodnje govora na svakoj razini, proces bi se mogao odvijati isključivo serijski, što bi uvelike smanjilo brzinu procesiranja (Berg 1986, Blackmer i Mitton 1991, Levelt 1989).

Stemberger (1985) i Dell (1986) su razvili prvi detaljni model interaktivnog širenja aktivacije u govornoj proizvodnji. Teorija se temelji na interaktivnoj mreži jedinica, kao što su riječi, morfemi, fonemi, te generativna pravila kojima se stvaraju utori (engl. slots) za jedinice. U ovom modelu odluke se donose na temelju stupnja aktivacije čvorova (engl. nodes) koji predstavljaju jedinice. Jedinice s najvećim stupnjem aktivacije bit će izabrane za daljnje procesiranje. Dell (1986) smatra da se aktivacija može širiti u dva smjera, odozgo prema dolje i obrnuto, npr. od riječi do morfema, od morfema do fonema, ali i obrnuto. Percepcija govora se odvija tijekom aktivacije odozdo prema gore, te je ovaj mehanizam na snazi kada govornik provjerava svoj vlastiti govor. Prema tome, pretpostavlja se da je monitoring bitno svojstvo razumijevanja i proizvodnje govora, te sastavni dio istih procesa, a postojanje odvojenog uređaja za monitoring se isključuje. U paralelnom i interaktivnom okviru govorne proizvodnje monitoring je "an automatic by-product of bottom-up activation spreading“" (Berg 1986: 139). Međutim, postoje neke nejasnoće vezane uz sam monitoring. Prvo, ukoliko bi pogreške automatski bile otkrivene, monitor bi trebao registrirati sve pogreške i potom dati naredbu za ispravak (Levelt 1989). Empirijska istraživanja su ukazala da govornici ne ispravljaju svaku pogrešku u svom govoru. Drugo, monitoring ne uključuje samo prepoznavanje lingvistički neispravnog izlaznog podatka, već i otkri- 
vanje pragmatički neprikladne informacije koju treba prenijeti, a modeli širenja aktivacije ne objašnjavaju ovaj važan aspekt monitoringa (Levelt 1992).

Na temelju spoznaja teorija predartikulacijskog monitoringa i širenja aktivacije, Levelt $(1983,1989)$ je razvio novi model za otkrivanje pogrešnog izlaznog podatka, slika 1. Od teorije predartikulacijskog uređivača Levelt je preuzeo stav da se predartikulacijski izlazni podatak može provjeriti. Od teorije širenja aktivacije prihvatio je stav da se isti mehanizam može primijeniti u službi provjeravanja ispravnosti vlastitog izričaja, kao i u percepciji i provjeravanju izričaja sugovornika. U Leveltovu modelu su procesne komponente ,specijalisti“ $u$ određenim funkcijama koje moraju izvršiti, što znači da one ne dijele procesne funkcije. Sastavnica ili modul će početi procesiranje jedino ako dobije karakterističan ulaz. Levelt pretpostavlja da je procesiranje inkrementalno, to jest da procesor koji slijedi može početi s radom i prije negoli je dovršen izlazni podatak iz prethodnog procesora. Nakon što je dio predverbalne poruke proslijeđen formulatoru, konceptualizator počinje raditi na idućem dijelu poruke, neovisno o tome je li se prethodni dio poruke još uvijek procesira, slika 1. Kao posljedica, artikulacija izričaja može početi puno ranije nego što je govornik završio planiranje cijele poruke. Svi procesori mogu raditi paralelno, ali ne istovremeno na istom dijelu izričaja koji se stvara, već na drugim njegovim dijelovima (Erdeljac 2009). Ovo je moguće jer je većina mehanizama u proizvodnji J1 govora, poglavito u fazi kodiranja, potpuno automatizirana. Inkrementalna, paralelna i automatizirana priroda procesiranja se podrazumijeva kako bi se objasnila velika brzina proizvodnje govora. Predverbalni plan je izlazni podatak konceptualizatora i istovremeno ulazni podatak idućeg modula za procesiranje, formulatora, koji ima zadatak izabrati leksičke jedinice i izvršiti gramatičko i fonološko kodiranje. Formulator "translates a conceptual structure into a linguistic structure" (Levelt 1989: 11). Formulator priziva informaciju iz govornikovog mentalnog leksikona, koji se u Leveltovu modelu sastoji od leksičkih unosa, a svaki se sastoji od a) lema ${ }^{2}$, koje određuju značenje i sintaksu leksičkoga unosa; b) leksema, koji nose informaciju o morfofonološkom obliku leksičkog unosa.

Osnovni postupak koji se događa u formulatoru je aktivacija lema. Govornik će prizvati lemu čije značenje najbolje odgovara semantičkoj informaciji

${ }^{2}$ Lema se koristi kao tehnički termin samo za sintaktička obilježja riječi, koje su određene sintaktički i semantički, ali ne i fonološki (Erdeljac 2009). 
koju nosi odgovarajući dio predverbalnog plana. Formulator preuzima predverbalnu poruku, kodira je gramatički i fonološki, te proizvodi fonetski i artikulacijski plan. Gramatički procesor pristupa lemama u leksikonu, stvara sintaktičke sastavnice (imenska fraza, glagolska fraza, itd.), te proizvodi linearni niz elemenata. Fonološki procesor pristupa formalnom dijelu leksikona i pridaje morfološki i fonološki oblik izričaju, uključujući prozodijske osobine.

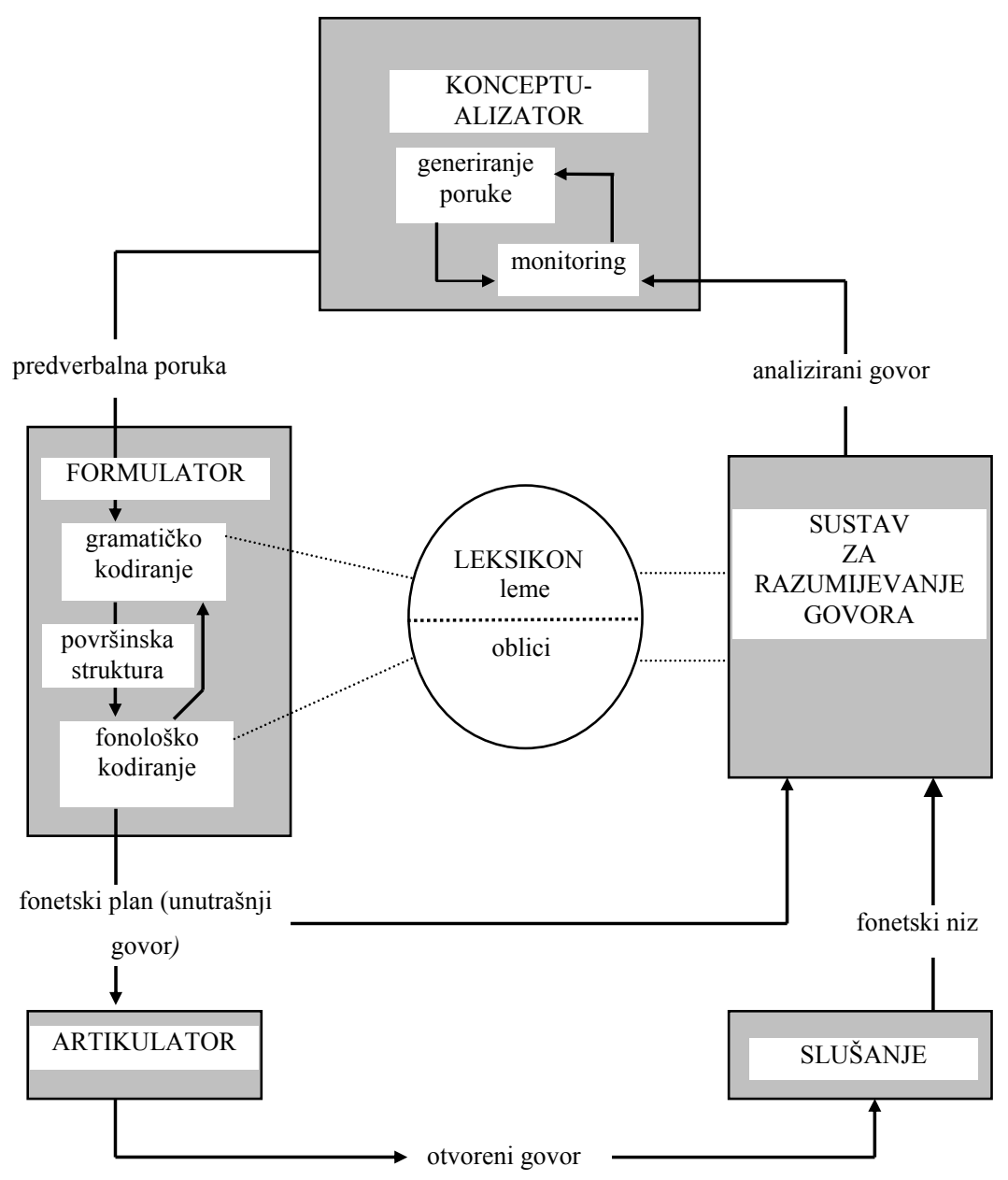

Slika 1: Leveltov prikaz procesa uključenih u stvaranje izričaja 
U Leveltovu sustavu procesiranja govornik nadgledava proizvodnju izričaja uz pomoć jednosmjernih «petlji» (engl. monitor loops) povezanih s monitorom, slika 1. To su direktni kanali povratne sprege koji se vraćaju prema monitoru kako bi provjerio konačni proizvod procesa proizvodnje. Prva petlja provjerava predverbalni plan s prvobitnom namjerom govornika prije nego se plan proslijedi formulatoru na daljnje procesiranje. Blackmer i Mitton (1991) te Levelt (1989) ovu petlju nazivaju konceptualnom petljom (engl. conceptual loop). Njezin zadatak je nadgledavanje prikladnosti izričaja, to jest otkrivanje konceptualnih i semantičkih pogrešaka. Blackmer i Mitton (1991) te Van Hest (1996) zaključuju da se konceptualne pogreške ispravljaju značajno sporije nego leksičke i fonološke. Razlog je činjenica da je teško odbaciti pogrešno odabran koncept, a drugi što je više vremena potrebno za samoispravljanje konceptualnih pogreška, jer se zahtijeva odabir nove komunikacijske namjere (Postma 2000).

Druga petlja ili unutrašnja petlja (engl. inner loop) zadužena je za monitoring fonetskog plana ili tzv. unutrašnjeg govora prije artikulacije, što se naziva „prikriveni monitoring“ (engl. covert monitoring) (Postma i Kolk 1992, 1993, Postma, Kolk i Povel 1990, Wheeldon i Levelt 1995). Unutrašnja petlja omogućava govorniku otkriti pogrešku prije nego se ona manifestira na površini. Levelt (1989) tvrdi da ovaj parsing, odnosno određivanje rečenične strukture, traje otprilike 150-200 ms nakon što je generiran fonetski plan, a pogreška će biti uočena otprilike $150 \mathrm{~ms}$ nakon njezine pojave na razini fonetskog plana. Artikulator će realizirati govorni plan nakon $200-250 \mathrm{~ms}$. Na taj mu način ostaje otprilike $100 \mathrm{~ms}$ za otkrivanje i ispravak prije nego što dođe do vanjske realizacije. Čak je i više vremena dostupno ukoliko je fonetski plan privremeno pohranjen, dok čeka na artikulacijsku realizaciju (Postma 2000). Ključno je pitanje veličine međuspremnika i brzine artikulacije. Blackmer i Mitton (1991) smatraju da je posebni potprogram ponovnog započinjanja (engl. restart) lociran između artikulacijskog međuspremnika i artikulacijske razine. Postma i Kolk (1993) ovaj potprogram nazivaju monitorom proračuna vremena između međuspremnika i artikulacije (engl. buffer-articulation timing monitor) koji je osjetljiv na timing novog materijala koji treba artikulirati. Ukoliko novi ulazni podatak nije dostupan u trenutku kada je artikulator završio s realizacijom određenog govornog programa, a rečenica nije završena, zasigurno se pojavila pogreška. Pretpostavljaju da artikulator posjeduje autonomnu sposobnost ponovnog započinjanja koji tada reagira na 
način da realizira stari program po drugi put, odnosno dolazi do ponavljanja. To se najčešće događa pri velikim brzinama govora, koje onemogućuju privremeno pohranjivanje i time povećavaju mogućnost pogrešnog vremenskog proračuna, što rezultira ponavljanjima kraćih govornih odsječaka. Otkrivanje pogreške prije njezine vanjske manifestacije ovisi o dostupnosti i kapacitetu artikulacijskog međuspremnika. Veća brzina govora smanjuje privremeno pohranjivanje (Blackmer i Mitton 1991, Levelt 1989, Van Hest 1996). Oomen i Postma (2001) su koristeći modificirani Leveltov (1989) zadatak manipulirali brzinom govora. Ispitanici su trebali opisati brže ili sporije kretanje točkice unutar mreže. Uočen je značajno povećani kognitivni napor pri većim brzinama govora, a disfluentnosti su slijedile određeni obrazac: ispitanici su pri većim brzinama govora proizvodili više ponavljanja, ali nisu učestalije koristili poštapalicu $u h$. Ponavljanja su objašnjena artikulatorovom sposobnošću autonomnog započinjanja (Blackmer i Mitton 1991). Ukoliko zbog povećanog kognitivnog napora fonetski plan nije sinkroniziran s procesom artikulacije, tada će se artikulacija postojećeg fonetskog plana restartirati, rezultirajući ponavljanjem već izgovorenih odsječaka.

Proizvedeni izričaj provjerava se i nakon artikulacije, što sačinjava posljednju, vanjsku petlju monitoringa (engl. external loop of monitoring), koja uključuje akustičko-fonetski procesor. Nakon što zapazi pogrešku ili neprikladnost u bilo kojoj od faza procesiranja, monitor izdaje alarmni signal, te se isti mehanizmi za proizvodnju govora pokreću po drugi put. Ukoliko se dogodi pogreška u procesu govornog kodiranja, isti će se predverbalni plan ponovno izdati i procesirati, u nadi da će ovaj put izlazni podatak biti bez pogreške. Ukoliko postoji neslaganje između predverbalnog plana i govornikove prvobitne namjere, odnosno ukoliko govornik primijeti da je poruka neadekvatna ili neprecizna, konceptualizator će proizvesti novu poruku, koja će se potom kodirati u formulatoru.

Istraživači polaze od pretpostavke da se prikrivena (engl. covert) samoispravljanja odvijaju na isti način kao i otkrivena (engl. overt) samoispravljanja (Levelt 1983, Berg 1986, Postma, Kolk i Povel 1990, Blackmer i Mitton 1991, Postma i Kolk 1992, 1993). S obzirom da ispravak nije artikuliran, prisustvo indirektnih manifestacija poput ponavljanja, zamuckivanja, produžavanja glasnika, te tihe stanke upućuju na postojanje takvog procesa (Postma i Kolk 1992). "Covert repairs are problematic data in that it is almost always impossible to determine what the speaker is monitoring for" (Levelt 1983: 55). 
Levelt (1983) smatra da je svako oklijevanje koje uključuje poštapalicu $u h$ uključeno u kategoriju prikrivenih ispravaka. "Quite common are covert repairs where the same word is repeated without change" (Levelt 1983: 44). Postma (2000) također navodi da su prikriveni ispravci često vrlo nejasni, te da ih je teško klasificirati.

As such, certain classes of hesitations sometimes are considered covert repairs, and sometimes they are not regarded as real repair phenomena, but more as the direct result of difficulties in word finding or conceptual selection (Postma 2000: 106).

Levelt (1983) pretpostavlja da su različiti oblici govornih disfluentnosti, kao što su zvučne stanke (engl. filled pauses), produžavanja vokala i ponavljanja znakovi prikrivenog ispravka. Postma i Kolk (1993) su mišljenja da prikriveno ispravljanje ima važnu ulogu u teoriji mucanja. Navedeni autori smatraju da su disfluentnosti kod mucanja uvjetovane predartikulacijskim prekidom govora, te da ljudi koji mucaju imaju poremećaj u fonološkom kodiranju koji vodi do velikog broja pogrešaka u govornom planu. Pod pretpostavkom da unutrašnji monitor ${ }^{3}$ radi normalno, mnoge pogreške će biti ispravljene prije artikulacije ili prikriveno, što će za posljedicu imati mucanje. Međutim, istraživači naglašavaju da se oklijevanja i ponavljanja mogu pripisati i nekim drugim faktorima osim prikrivenom ispravku, prvenstveno povećanom naporu kod procesiranja, privremenoj nedostupnosti traženog dijela informacije ili planiranju jedinica unaprijed (Garrett 1982, Clark i Wasow 1998). Tako Lennon (1990) smatra da su ponavljanja i popunjene stanke međusobno povezane te su u službi rješavanja problema u planiranju izričaja, za razliku od samoispravljanja, koja nisu vezana uz njih i u službi su drugačijih funkcija u proizvodnji govora.

Maclay i Osgood (1959), Lickley (1994), te Rieger (2003) su analizom ponavljanja zaključili da se funkcionalne riječi, kao što su prijedlozi i članovi, mnogo češće ponavljaju nego riječi koje nose sadržaj, poput imenica i glagola. Fox, Hayashi i Jasperson (1996) analizirali su razlike u samoispravljanjima $\mathrm{u}$ engleskom $\mathrm{i}$ japanskom te razlike u proizvodnji ponavljanja. Rezultati pokazuju da Englezi u svom govoru koriste ponavljanja kako bi odgodili proizvodn-

${ }^{3}$ Leveltova teorija $(1983,1989)$ monitoringa sadrži unutrašnji monitor koji radi na predartikulacijskoj reprezentaciji izričaja (fonetskom planu). 
ju imenice, za razliku od Japanaca koji ne koriste tu strategiju. Englezi ponavljaju članove i prijedloge kako bi dobili na vremenu prilikom traženja imenice, za razliku od Japanaca koji koriste drugačije strategije kupovanja vremena. Zaključuju da je fenomen ponavljanja uvjetovan specifičnostima jezika.

Riegerovi (2003) ispitanici su osmero bilingvalnih govornika, koji koriste engleski i njemački podjednako. Kvalitativna analiza podataka otkriva da su osnovne funkcije ponavljanja kao samoispravljanja u engleskom i njemačkom odgađanje proizvodnje i/ili onemogućavanje sugovornika da preuzme riječ. Ponavljanje omogućuje govorniku ostati u komunikaciji ili mu daje vrijeme potrebno za pronalaženje određene riječi ili konstrukcije. Englesko-njemački bilingvalni govornici drugačije koriste ponavljanja kao strategiju samoispravljanja, ovisno o jeziku koji trenutno govore. Ispitanici u engleskom češće nego u njemačkom jeziku ponavljaju osobne zamjenice, kombinacije zamjenica-glagol i prijedloge, te ,recikliraju“ više pokaznih zamjenica u njemačkom nego u engleskom. Rieger ove pojave objašnjava razlikama u morfosintaktičkim strukturama engleskog i njemačkog jezika, te potvrđuje stajalište da su ponavljanja fenomen koji počiva na pravilima, a ne kaotični aspekt govornog diskursa (Schegloff 1979, Shriberg 1994, Fox, Hayashi i Jasperson 1996, Rieger 2000).

Branigan, Lickley i McKelvie (1999) proučavali su ulogu nelingvističkih faktora u proizvodnji ponavljanja. Govornici koji nisu mogli vidjeti sugovornika proizvodili su više ponavljanja od onih koji su ga mogli vidjeti. Zadatak je uključivao opisivanje puta na karti, a pri ponavljanju istog zadatka zabilježeno je manje ponavljanja nego prvi put. Zaključili su da očni kontakt i upoznatost sa zadatkom utječe na pojavu ponavljanja i samoispravljanja.

Horga (2008) je promatrajući spontani razgovor u radijskim emisijama analizirao osobitosti prekida izričaja u okviru modela kojeg je nazvao PPP-model (Prekinuto dio, Prekid, Ponovljeni dio). Izdvaja dvije vrste PPP-segmenata: prvi s kraćim prekinutim dijelom i kraćim prekidom, te drugi s dužim trajanjem ovih dvaju dijelova PPP-segmenata. Fenomen ponavljanja objašnjava teorijom aktivacijskog širenja (Dell 1986), kada se tijekom govorne proizvodnje aktiviraju čvorovi na različitim razinama govorne reprezentacije (razlikovna obilježja, fonemi, slogovi, morfemi, riječi), tako da neadekvatna aktivacija pojedinih čvorova uzrokuje govorne pogreške, ali i prekide izgovornog programa. Kako bi se element serijski ugradio u izričaj, on mora u pravom trenutku biti dovoljno aktivan, ali se njegova aktivnost također 
mora smanjiti kako bi ustupila mjesto sljedećem elementu. Ponavljanje nastaje kao rezultat produžene aktivacije nekog elementa i nedovoljne aktivacije sljedećeg koji bi ga trebao zamijeniti. Ovo se osobito odnosi na slučajeve kada je prekinuti dio kratak i gdje je prekid nultog trajanja. U takvim se slučajevima radi o problemima na nižoj, to jest artikulacijskoj razini. Drugu vrstu ponavljanja čine slučajevi kada se za vrijeme prekida pojavljuje neki oblik disfluentnosti: nefonemski odsječak, produženi vokal, tiha stanka ili kada se za vrijeme prekida prekinuti dio ponavlja nekoliko puta. Ovakav tip ponavljanja objašnjava se problemima na konceptualnoj razini, kada govornik u dijelu prekida izvedbe planira sljedeće elemente izričaja. Problemi na višoj jezičnoj, odnosno konceptualnoj razini zahtijevaju uključivanje centralnih mehanizama kako bi se odbacio krivi program i programirao novi. Sa stajališta povratnih sprega, PPP segment je pod kontrolom prije svega unutarnjih povratnih sprega koje su brze, te znatno brže od izvanjskih slušnih i povratnih sprega.

\section{Cilj i metodološki postupci}

Cilj rada je istražiti osobitosti ponavljanja u proizvodnji materinskog jezika, odnosno analizirani su prekidi izričaja u J1 kada govornik nije pogriješio te se ne ispravlja, nego nastavlja započeti izričaj ponavljajući jedan njegov dio. Izračunate su različite veličine koje opisuju učestalost i trajanje ponavljanja u slogovima i riječima, te su prikazani frekvencijski dijagrami trajanja i broja ponavljanja po minuti. Na temelju dobivenih rezultata doneseni su odgovarajući zaključci koji se odnose na prirodu ponavljanja u J1 proizvodnji.

Ispitivanje se provelo na uzorku od 101-og ispitanika, studenata prve godine Fakulteta elektrotehnike, strojarstva i brodogradnje u Splitu. Varijable povezane s ponavljanjima su ispitane na testovima govornog opisivanja statičkih i vremenskih situacijskih konstelacija. U prvom zadatku studenti su pogledali crtani film koji je odabran zbog pretpostavke da sadržaj predstavlja značajan kognitivni napor u smislu diskursne organizacije. Drugi i treći zadatak su uključivali opisivanje rasporeda namještaja u prostoriji, a u četvrtom zadatku su ispitanici na temelju crteža oblikovali sadržajno nepovezane izričaje. U petom zadatku su ispitanici na temelju crteža trebali ispričati priču. Varijable fluentnosti govora zabilježene su na temelju individualnog audio-snimanja govornika, a zvučne zapise transkribirala autorica. 


\section{Rezultati i rasprava}

Ispitanici su izgovorili ukupno 52795 riječi u svim zadacima. Ako se podaci razmatraju u vremenskoj domeni, treba naglasiti da su ispitanici govorili gotovo punih 8 sati. Ukupni broj zabilježenih ponavljanja je 770. Ako se broj ponavljanja reducira na 100 riječi dobiva se iznos od 1.458. Ukupni broj ponavljanja po jednom satu je 96.887 , a po minuti 1.615. Prosječni broj riječi nakon kojeg dolazi do ponavljanja je 68.565. Srednji broj slogova koji se ponavljaju je 1.834 , a riječi 1.123 .

Frekvencijski dijagram trajanja ponavljanja u slogovima prikazan je na slici 2a, gdje je $s_{p n}$ trajanje ponavljanja u slogovima, pri čemu $s_{p n}=0.5$ znači da se radi o ponavljanju jednog nepotpunog (prekinutog) sloga (...i ona ih je o-odvela kod sebe doma...), dok $s_{p n}=1.5$ znači da se radi o ponavljanju jednog sloga i nepotpunog drugog sloga (...i pošto je prošlo par sati majk-majka se nije vraćala...), itd. Iz dijagrama je očito da se ponavljanje jednog nepotpunog sloga događa u 143 slučaja (18.571\%), dok se ponavljanje s nepotpunim drugim, trećim i daljnjim slogom događa ukupno u tek 60 slučajeva (7.792\%). Može se zaključiti da se prilikom ponavljanja načelno poštuje cjelovitost slogova, osim u slučaju ponavljanja jednog nepotpunog sloga. Također, 420 od ukupno 770 ponavljanja ima trajanje do jednog potpunog sloga (54.545\%), što govori o činjenici da apsolutna većina svih ponavljanja ima iznimno kratko trajanje. Na slici 2 b je prikazan dijagram kumulativnih frekvencija trajanja ponavljanja u slogovima. Vidljivo je da je preko $3 / 4$ ponavljanja u trajanju do uključivo dva sloga.

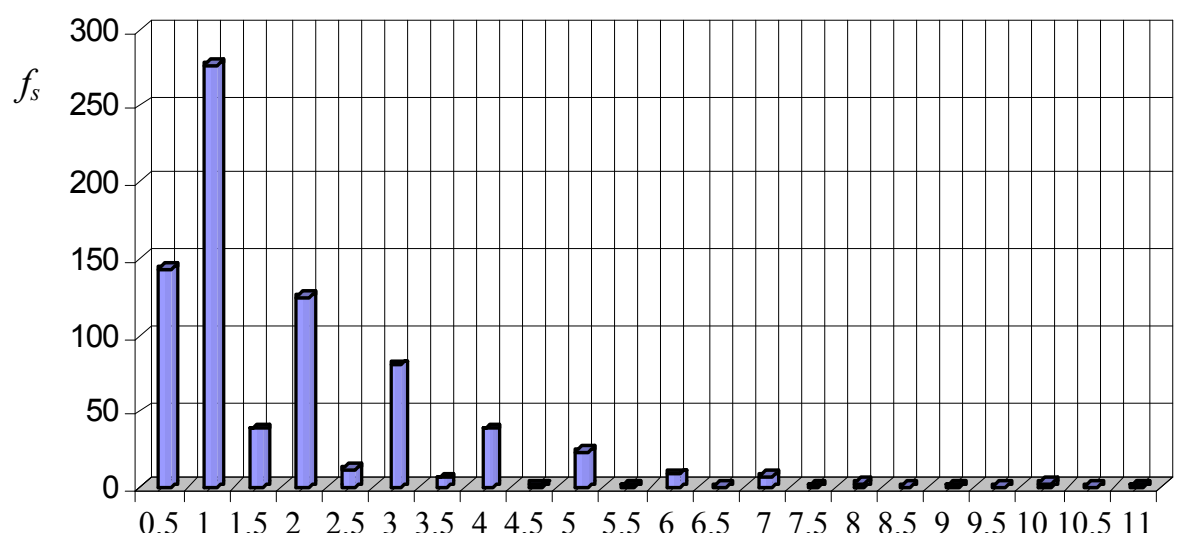

Slika 2a: Frekvencijski dijagram trajanja ponavljanja u slogovima u J1 


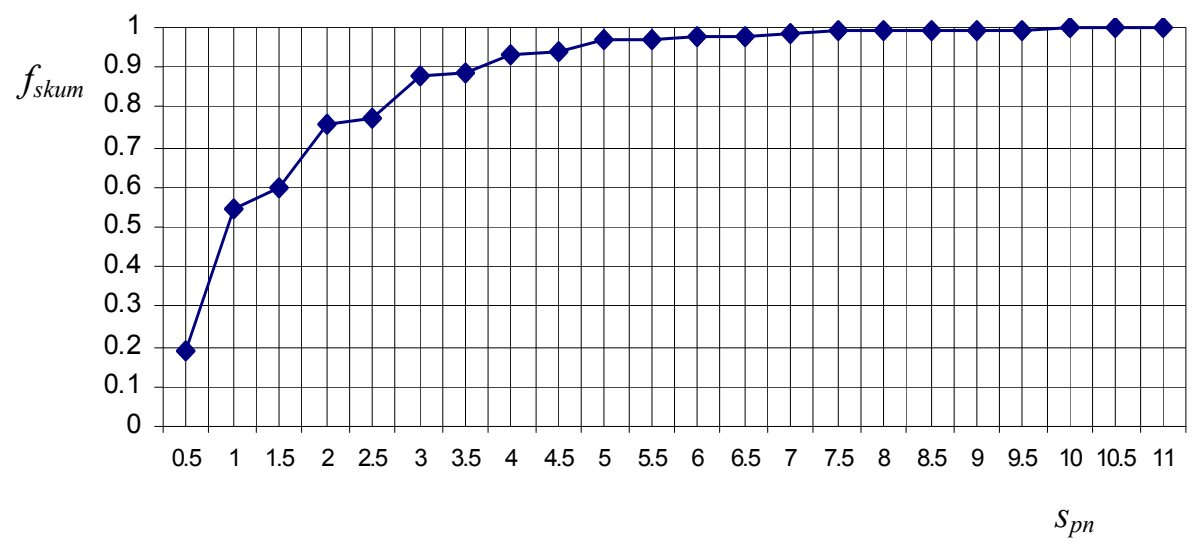

Slika 2b: Dijagram kumulativnih frekvencija trajanja ponavljanja u slogovima u J1

Frekvencijski dijagram trajanja ponavljanja u riječima prikazan je na slici 3a. Ponavljanje nepotpune jedne riječi (...ipak je to chronos gospodar vremena koji svoje ime ponavlja po-popriličan broj puta) događa se u 266 slučajeva $(34.545 \%)$, dok se ponavljanje s nepotpunom drugom (na počet- $\mathrm{hm}$ na početku crtića...), trećom i daljnjom riječi događa samo u 30 slučajeva (3.896\%). Zaključuje se da se gotovo potpuno poštuje cjelovitost riječi, osim ukoliko se ne radi o slučaju ponavljanja jedne nepotpune (prekinute) riječi. Iz dijagrama kumulativnih frekvencija prikazanih na slici $3 b$ može se primijetiti da je gotovo 4/5 ponavljanja u trajanju do uključivo jedne riječi (prekinuta riječ ili jedna dovršena riječ) (...Johnny se pobojao da se maj-majci nije nešto dogodilo....).

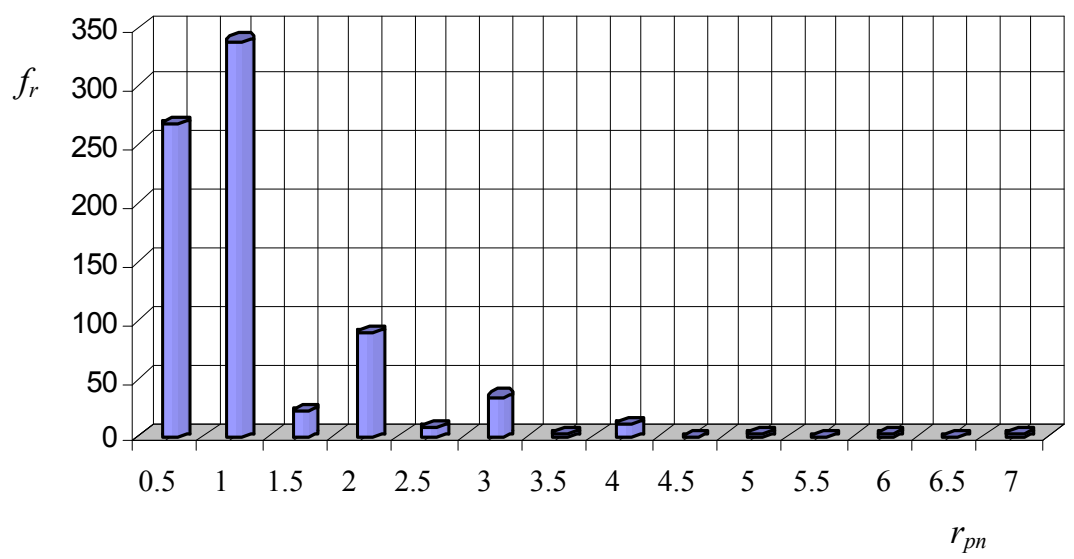

Slika 3a: Frekvencijski dijagram trajanja ponavljanja u riječima u J1 


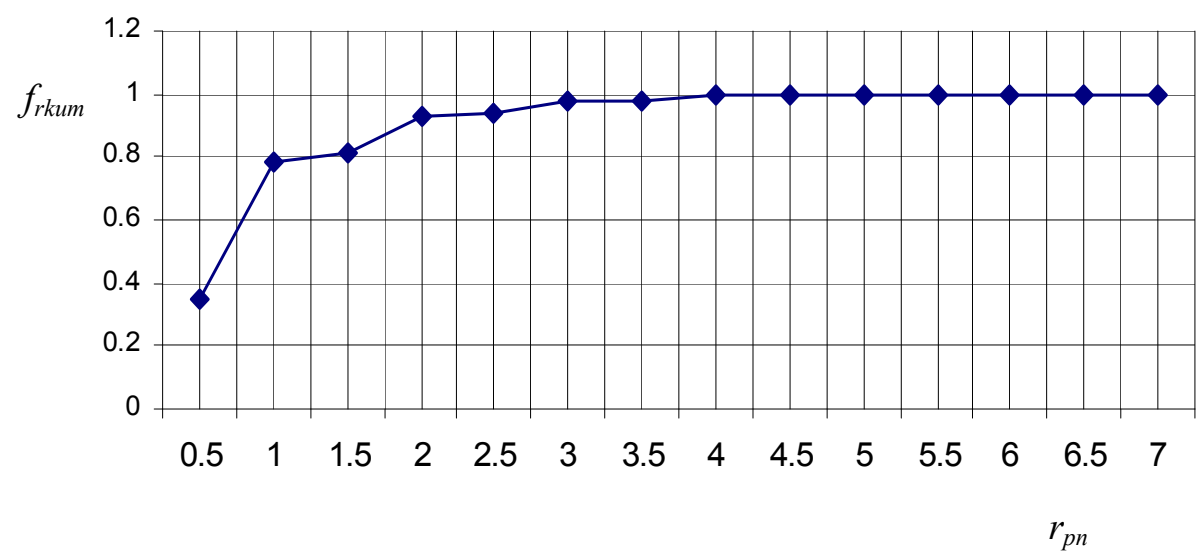

Slika 3b: Dijagram kumulativnih frekvencija trajanja ponavljanja u riječima u J1

U tablici 1 izvedena je kratka raščlamba višestrukosti ponavljanja. Može se primijetiti da ni u jednom slučaju od ukupno 770 ponavljanja nije zabilježeno trostruko ponavljanje. Uvjerljiva većina svih ponavljanja su jednostruka (96.623\%), a tek $3.377 \%$ odnosi se na dvostruka ponavljanja (Johnnyeva majka je počela-počela hm počela pjevati...).

\begin{tabular}{c|c|c} 
Ponavljanja & $\boldsymbol{N}_{\boldsymbol{p n}}$ & $\boldsymbol{p}_{\boldsymbol{p n}}(\%)$ \\
\hline jednostruka & 744 & 96.623 \\
\hline dvostruka & 26 & 3.377 \\
\hline ukupno & 770 & 100
\end{tabular}

$\mathrm{N}_{\mathrm{pn}}$ - ukupni broj ponavljanja, $\mathrm{p}_{\mathrm{pn}}$ - postotni udjel jednostrukih, odnosno dvostrukih ponavljanja

Tablica 1: Višestruka ponavljanja u J1

$\mathrm{Na}$ slici 4a prikazan je frekvencijski dijagram pojavljivanja nultog prekida i pojedinih oblika disfluentnosti koje prethode ponavljanju, dok su na slici 4b prikazani njima pripadajući postotni udjeli (Johnny Bravo se naš- ovaj našao u zamci...). S obje slike vidljivo je da apsolutna većina svih ponovljenih segmenata nije prethođena nekim vidom disfluentnosti, već se radi o ponavl- 
janjima s nultim prekidom (... i uglavnom došao je do-do neke špilje u kojoj je bio medvjed). Vrlo sličan postotni udjel (52\%) za nulte prekide dobiven je u istraživanju koje je proveo Horga (2008). Ponavljanja s nultim prekidom su rezultat pogreške koja nastaje u trenutku kada je artikulator završio s realizacijom određenog govornog programa, a novi ulazni podatak nije dostupan, te artikulator realizira stari program po drugi put (Blackmer i Mitton 1991). Ponavljanja popraćena različitim oblicima disfluentnosti upućuju na probleme na razini planiranja kada govornik ponavljanjem „kupuje vrijeme”, odnosno planira sljedeće elemente izričaja (Horga 2008).

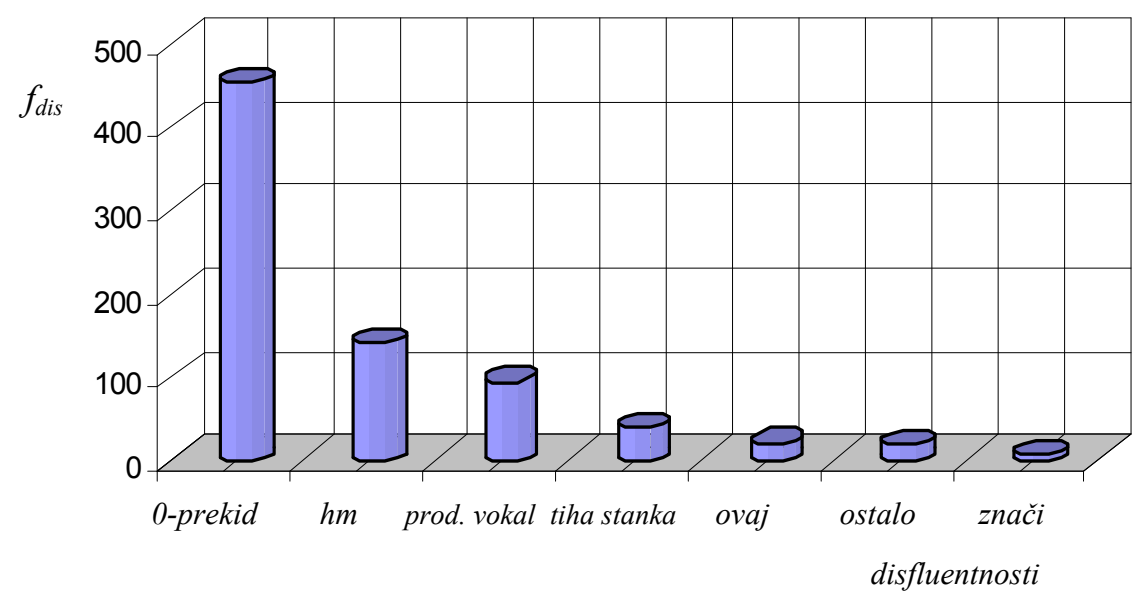

Slika 4a: Frekvencijski dijagram pojavljivanja nultog prekida i pojedinih oblika disfluentnosti kod ponavljanja u J1
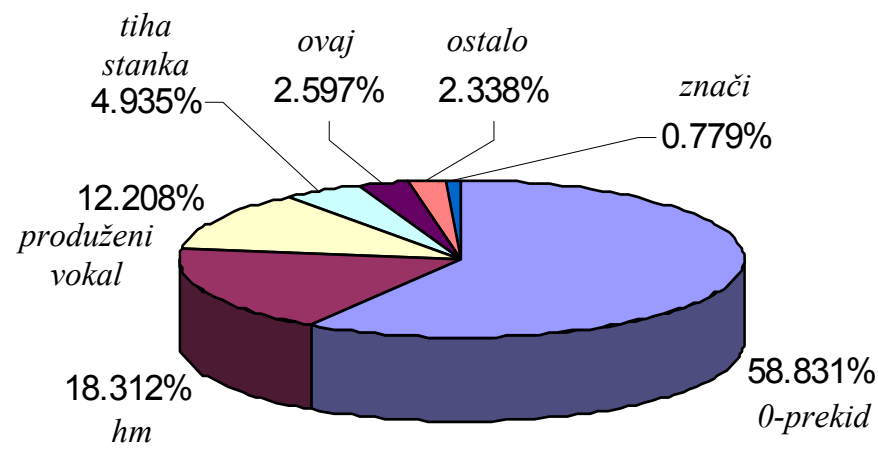

Slika 4b: Postotni udjel pojavljivanja nultog prekida i pojedinih oblika disfluentnosti kod ponavljanja u J1 
Na slici 5a prikazan je frekvencijski dijagram broja ponavljanja po minuti. $\mathrm{Na}$ osi apscisa označene su sredine razreda koje se odnose na broj ponavljanja po minuti, npr. $n_{\text {pnm }}=0.25$ predstavlja sredinu razreda $[0,0.5]$. Na osi ordinata nanesene su frekvencije ispitanika, čiji brojevi ponavljanja pripadaju pojedinom razredu. Vidljivo je da se najveća frekvencija pojavljuje za razred $[0.5,1]$, odnosno 22 govornika naprave između $0.5 \mathrm{i}$ jednog ponavljanja u minuti. Učestalost naglo počinje opadati nakon dva ponavljanja u minuti, a nakon tri ponavljanja po minuti ima vrlo malene iznose. Dijagram kumulativnih frekvencija pojavljivanja broja ponavljanja po minuti, slika $5 \mathrm{~b}$, ukazuje da oko $3 / 4$ ispitanika ima do uključivo 2 ponavljanja po minuti.

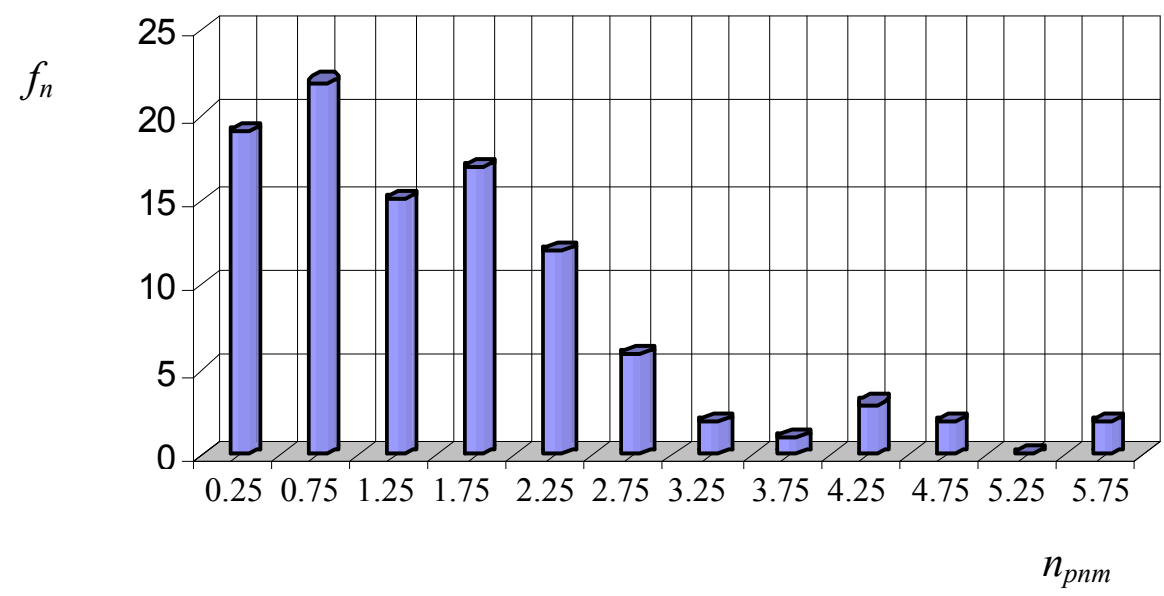

Slika 5a: Frekvencijski dijagram broja ponavljanja po minuti u J1

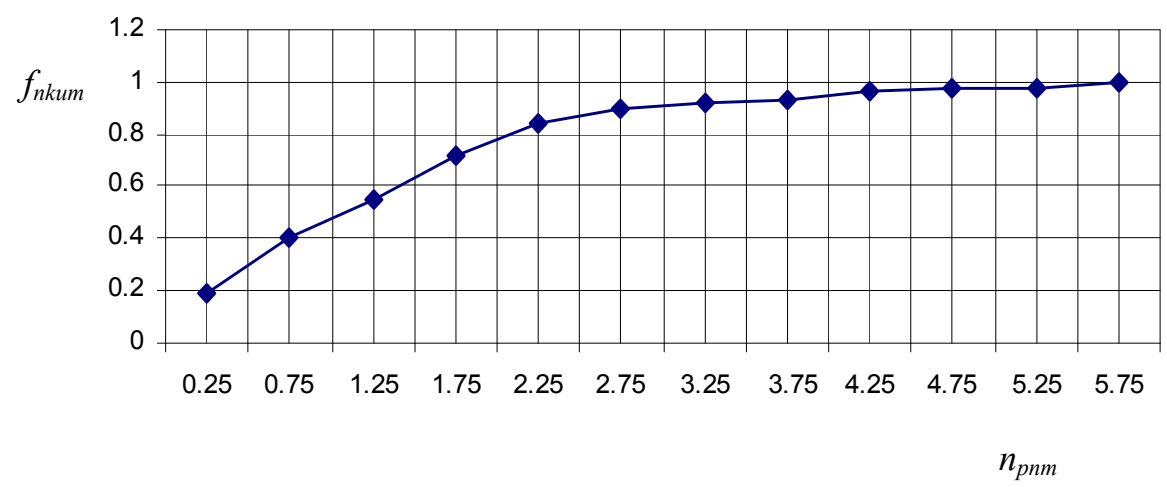

Slika 5b: Dijagram kumulativnih frekvencija broja ponavljanja po minuti u J1 
Na slici 6a prikazan je frekvencijski dijagram broja ponavljanja na 100 riječi, a na slici $6 \mathrm{~b}$ njemu pripadajući dijagram kumulativnih frekvencija. $\mathrm{Na}$ osi apscisa nanesene su sredine razreda koje se odnose na broj ponavljanja na 100 riječi, dok su na osi ordinata frekvencije ispitanika čiji brojevi ponavljanja na 100 riječi pripadaju pojedinom razredu. Na slici 6a može se primijetiti da se najveće frekvencije ispitanika odnose na prva dva razreda, to jest razrede koji zbirno uključuju interval od nula do jednog ponavljanja na 100 riječi. $\mathrm{U}$ navedene razrede pripada gotovo polovica ispitanika. Također, uočava se da frekvencija ispitanika naglo opada nakon dva ponavljanja na 100 riječi, te da je mali ukupni broj ispitanika koji imaju više od tri ponavljanja na sto riječi. Dijagram kumulativnih frekvencija, slika 6b, ukazuje da preko $3 / 4$ ispitanika ima do uključivo dva ponavljanja na 100 riječi.

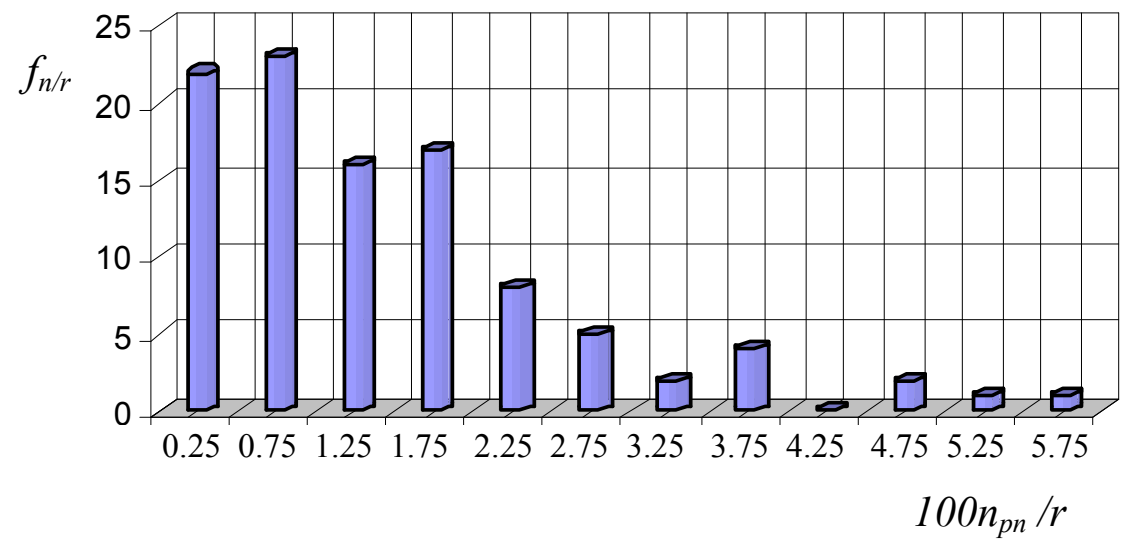

Slika 6a: Frekvencijski dijagram broja ponavljanja na 100 riječi u J1

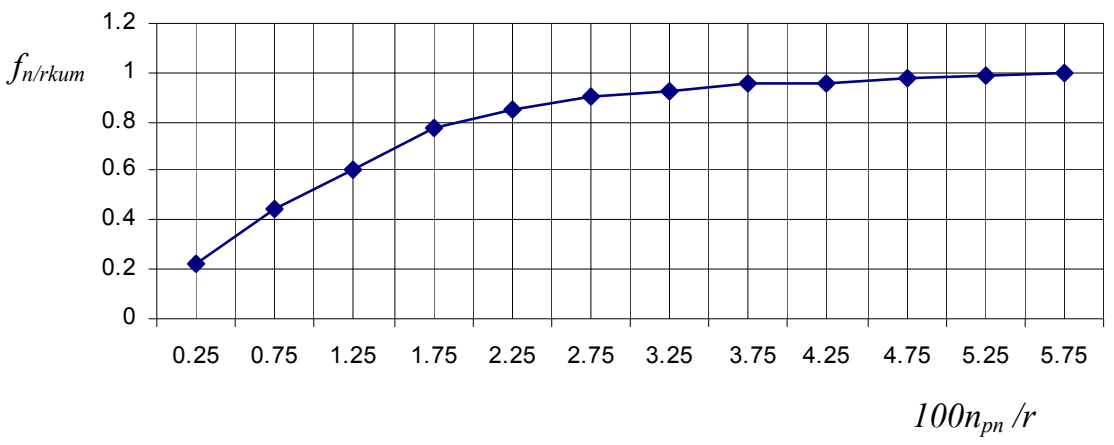

Slika 6b: Dijagram kumulativnih frekvencija broja ponavljanja na 100 riječi u J1 
U tablici 2 uspoređeni su pojedini parametri ponavljanja dobiveni u ovom radu s onima objavljenim u Horginom (2008) radu. Horga (2008) je na uzorku radijskog programa dobio interval od 48 sekunda između dva ponavljanja, što ne odstupa značajno od 37.156 sekunda dobivenih u ovom radu. Prosječni broj slogova po jednom ponavljanju u ovom radu je 1.834, dok je u Horginom (2008) radu jednak 1.64, što također ukazuje na dobro slaganje rezultata.

\begin{tabular}{c|c|c}
$\begin{array}{c}\text { Parametri } \\
\text { ponavljanja }\end{array}$ & Horga 2008 & Kovač, Horga 2010 \\
\hline $\mathbf{N}_{\mathrm{pn}}$ & 103 & 770 \\
\hline $\mathbf{t}_{\mathbf{s}} / \mathbf{N}_{\mathrm{pn}}$ & 48 & 37.156 \\
\hline $\mathbf{S}_{\mathbf{p n}} / \mathbf{N}_{\mathrm{pn}}$ & 1.64 & 1.834
\end{tabular}

$\mathrm{N}_{\mathrm{pn}}$ - ukupni broj ponavljanja, $\mathrm{t}_{\mathrm{s}}, / \mathrm{N}_{\mathrm{pn}}$ - broj sekundi po jednom ponavljanju, $\mathrm{S}_{\mathrm{pn}} / \mathrm{N}_{\mathrm{pn}}$ - prosječni broj slogova koji se ponavljaju po ponavljanju

Tablica 2: Usporedba parametara ponavljanja u J1 s Horga (2008)

\section{Zaključak}

Ponavljanja kao oblici govorne disfluentnosti mogu se pojaviti zbog problema na višoj, konceptualnoj razini procesiranja uslijed povećanog napora kod procesiranja, privremene nedostupnosti traženog dijela informacije ili planiranja jedinica unaprijed. Isto tako, problemi se mogu pojaviti na nižoj, artikulacijskoj razini procesiranja.

Analizom ponavljanja govornih odsječaka može se zaključiti da prilikom ponavljanja govornici načelno poštuju cjelovitost sloga ili riječi, ukoliko se ne radi o slučaju ponavljanja jednog nepotpunog (prekinutog) sloga ili riječi. Apsolutna većina svih ponavljanja ima vrlo kratko trajanje, do jednog ponovljenog cijelog sloga. Ponavljanjima u natpolovičnoj većini ne prethodi neki drugi oblik disfluentnosti. Tendencija ponavljanja kraćih govornih odsječaka u hrvatskom jeziku, koja nisu prethođena nekim drugim vidom disfluentnosti, ukazuje prvenstveno na probleme na nižoj razini procesiranja uslijed produžene aktivacije nekog elementa i nedovoljne aktivacije sljedećeg koji 
bi ga trebao zamijeniti. Ukoliko novi ulazni podatak nije dostupan u trenutku kada je artikulator završio s realizacijom određenog govornog programa, a izričaj nije dovršen, artikulator koji posjeduje autonomnu sposobnost ponovnog započinjanja reagira na način da realizira stari program po drugi put, što rezultira ponavljanjima kraćih govornih odsječaka s nultim prekidom. Provedena analiza potvrđuje stajalište da su ponavljanja u materinskom jeziku sustavno organizirani fenomen, a ne kaotični aspekt govornog diskursa.

Potrebno je naglasiti da je ovo istraživanje bilo usmjereno prema populaciji studenata tehničkih studija, te da bi buduća istraživanja mogla dati odgovor na pitanje vrijede li zaključci ovog rada i za opću populaciju.

\section{Literatura:}

Baars B. J., Motley M. T., MacKay D. G., 1975, Output editing for lexical status in artificially elicited slips of the tongue, Journal of Verbal Learning and Verbal Behaviour 14, s. 382-391.

Berg T., 1986, The problem of language control: Editing, monitoring and feedback, Psychological Research 48, s. 133-144.

Blackmer E. R., Mitton J. L., 1991, Theories of monitoring and the timing of repairs in spontaneous speech, Cognition 39, s. 173-194.

Bortfeld H., Leon S. D., Bloom J. E., Schober M. F. Brennan S. E., 2001, Disfluency Rate in Conversation: Effects of Age, Relationship, Topic, Role, and Gender, Language and Speech 44 (2), s. 123-147.

Branigan H., Lickley R., McKelvie D., 1999, Non-linguistic influences on rates of disfluency in spontaneous speech. Proceedings of the ICPhS. ICPhS, San Francisco, s. 387-390.

BREDART S., 1991, Word interruption in self-repairing, Journal of Psycholinguistic Research 20, s. 123-137.

Clark H. H., Wasow T., 1998, Repeating words in spontaneous speech, Cognitive Psychology 37, s. 201-242.

Dell G. S., 1986, A spreading activation theory of retrieval in sentence production, Psychological Review 93, s. 283-321.

ERDELJAC V., 2009, Mentalni leksikon: modeli i činjenice, Zagreb: Ibis grafika.

Fox B. A., Hayashi M., Jasperson R., 1996, Resources and repair: A cross-linguistic study of syntax and repair, U: E. Ochs, E. A. Schegloff, S. A. Thompson (ur.), Interaction and Grammar, Cambridge: Cambridge University Press, s. 185-237. 
Fox TRee J. E., 1995, The effects of false starts and repetitions on the processing of subsequent words in spontaneous speech, Journal of Memory and Language 34, s. 709-738.

Garnsey S. M., Dell S. G., 1984, Some neurolinguistic implications of prearticulatory editing in production, Brain and language 23, s. 64-73.

Garrett M. F., 1982, Production of speech: observations from normal and pathological language use, U: A. W. Ellis (ur.), Normality and pathology in cognitive functions, London: Academic Press, s. 19-76.

Horga D., 2008, Prekid izričaja i ponavljanje u govornoj proizvodnji, Philologica 11, s. $31-42$.

JAEGER J. J., 2005, Kids' slips. What young children's slips of the tongue reveal about language development, Mahwah, New Jersey and London: Lawrence Erlbaum Associates Publishers.

LENNON P., 1990, Investigating fluency in EFL: A quantitive approach, Language Learning 40, s. 387-417.

Levelt W. J. M., 1992, Accessing words in speech production: Stages, processes and representations, Cognition 42, s. 1-22.

Levelt W. J. M., 1993, Language use in normal speakers and its disorders, U: G. Blanken, J. Dittmann, H. Grimm, J. C.Marshall, C.-W. Wallesch (ur.), Linguistic disorders and pathologies, Berlin: deGruyter, s. 1-15.

LickLey R. J., 1994, Detecting Disfluency in Spontaneous Speech, doktorska disertacija, University of Edingburgh.

Maclay H., Osgood C. E., 1959, Hesitation phenomena in spontaneous English speech, Word 15, s. 19-44.

Mildner V., 2003, Govor između lijeve i desne hemisfere, Zagreb: IPC grupa.

Motley M. T., CAmden C. T., BaARs B. J., 1982, Covert formulation and editing of anomalies in speech production: Evidence from experimentally elicited slips of the tongue, Journal of Verbal Learning and Verbal Behaviour 21, s. 578-594.

NAKatani C. H., Hirschberg J., 1994, A corpus-based study of repair cues in spontaneous speech, The Journal of the Acoustical Society of America 95 (3), s. 1603-1616 .

Nоотевоом S., 1980, Speaking and unspeaking: detection and correction of phonological and lexical errors in spontaneous speech, U: V. A. Fromkin (ur.), Errors in linguistic performance: slips of the tongue, ear, pen and hand, New York: Academic Press, s. 87-96.

Norman D. A., 1981, Categorization of action slips, Psychological Review 88, s. 1-15.

Oomen C. C. E., Postma A., 2001, Effects of divided attention on the production of filled pauses and repetitions, Journal of Speech, Language and Hearing Research 44, s. 997-1004. 
Postma A., 2000, Detection of errors during speech production: A review of speech monitoring models, Cognition 77, s. 97-131.

Postma A., Kolk H., 1992, The effects of noise masking and required accuracy on speech errors disfluencies and self-repairs, Journal of Speech and Hearing Research 35, s. 537-544.

Postma A., Kolk H., 1993, The covert repair hypothesis: Prearticulatory repair processes in normal and stuttered disfluencies, Journal of Speech and Hearing Research 36, s. 472-487.

Postma A., Kolk H., Povel D. J., 1990, On the relation among speech errors, disfluencies and self repairs, Language and Speech 33, s. 19-29.

RIEGER C. L., 2000, Self-repair Strategies of English-German Bilinguals in Informal Conversations: The Role of Language, Gender and Proficiency, doktorska disertacija, University of Alberta.

Rieger C. L., 2003, Repetitions as self-repair strategies in English and German conversations, Journal of Pragmatics 35, s. 47-69.

Schegloff E. A., 1979, The relevance of repair to syntax-for-conversation, U: T. Givon (ur.), Syntax and Semantics 12: Discourse and Syntax, New York: Academic Press, s. 261-286.

Shriberg E. E., 1994, Preliminaries to a Theory of Speech Disfluencies, doktorska disertacija, University of California, Berkley.

Stemberger J. P., 1985, An interactive activation model of language production, U: A. W. Ellis (ur.), Progres in the psychology of language, Hillsdale NJ: Lawrence Erlbaum Associates, s. 143-186.

Van Hest G. W. C. M., 1996, Self-repair in L1 and L2 production, Tilburg: University Press.

Wheeldon L. R., Levelt W. J. M., 1995, Monitoring in the time course of phonological encoding, Journal of Memory and Language 34, s. 311-334.

WIESE R., 1984, Psycholinguistische Aspekte der Sprachproduktion: Sprechverhalten und Verbalisierungsprozesse, Düsseldorf: Universität Bielefeld.

\section{Repetitions as a form of speech disfluency}

(sum mary)

The paper analyses repetitions considered as a form of speech disfluency. A recorded speech sample, in the Croatian language, lasting for approximately eight hours has been transcribed. 101 students of technical studies at the Faculty of Electrical Engineering, Mechanical Engineering and Naval Architecture in Split took part in the recordings. Various quantities describing the frequency and duration of repetitions in syllables and words have been measured, and corresponding frequen- 
cy diagrams have been presented. The absolute majority of all repetitions is of very short duration, comprising up to one completed syllable. In most cases repetitions are not followed by any kind of disfluency. While repeating, the speakers usually respect the integrity of syllables or words, except when repeating one incomplete (interrupted) syllable or word. The tendency of repeating shorter speech fragments, which are not preceded by any kind of disfluency, points primarily to problems arising at lower processing levels. The results of this study confirm the view that repetitions are systematically organized phenomena and they are not a chaotic aspect of spoken discourse. 
